\title{
Effect of an asynchronous environment on embryonic development in sheep
}

\author{
I. Wilmut and D. I. Sales \\ A.R.C. Animal Breeding Research Organisation, West Mains Road, \\ Edinburgh EH9 3JQ, U.K.
}

\begin{abstract}
Summary. Sheep embryos which were transferred to recipients in oestrus 3 days before or 3 days after the donors were unable to implant even when a synchronously transferred embryo was developing successfully in the same uterus. Embryos which had spent 3 days in an advanced recipient were transferred to a recipient synchronous with the original donor. Embryos first transferred on Day 3 were slightly accelerated in their development, but retained the ability to implant normally in the 2nd recipient. By contrast, embryos first transferred on Day 6 were markedly stimulated and less able to implant in the second recipient.
\end{abstract}

\section{Introduction}

If mammalian embryos are transferred from one female to another by appropriate methods maximum conception is obtained when there is little difference in the interval from oestrus to surgery in donor and recipient females. This observation was first made in rabbits (Chang, 1950) and has been confirmed in many other laboratory and farm animals (see bibliographies by Adams \& Abbott, 1971; Adams, 1975). In sheep, conception rate is only slightly less than maximum if the interval from oestrus to surgery for donor and recipient ewes differs by 2 days, but almost no conception occurs if there is a 3-day difference (Moore \& Shelton, 1964; Rowson \& Moor, 1966). It is not known why embryos fail to implant in asynchronous recipients. Two hypotheses have been put forward (Rowson \& Moor, 1966): (1) failure to establish pregnancy may follow an inability of the embryo to prevent luteolysis or to provide other signals to the recipient; or (2) there may be a fatal modification in embryo development caused by exposure to an inappropriate uterine environment because embryonic development is modified in the uterus of an asynchronous recipient (Lawson, 1977) and in ewes treated with progesterone (Winten berger-Torres, 1967).

Both of these hypotheses have been tested in the present study.

\section{Materials and Methods}

The experiments were carried out between September 1978 and April 1979 at the ABRO Field Laboratory 10 miles south of Edinburgh. The ewes were all at least 18 months old and generally of proven fertility.

Oestrous cycles were synchronized by treatment for 12-15 days with vaginal sponges impregnated with $60 \mathrm{mg}$ medroxyprogesterone acetate (Veramix: Upjohn Ltd, Crawley, Sussex). After sponge withdrawal the occurrence of oestrus was checked twice daily by testing with vasectomized rams. Superovulation was induced in donors by i.m. injection of 1500 i.u. PMSG 
(Folligon: Intervet Ltd, Cambridge) on Day 12 of the first oestrous cycle after sponge withdrawal (Day 0 is day of onset of oestrus). At the second oestrus these ewes were hand-mated to rams of their own breed or cross, twice at an interval of approximately $12 \mathrm{~h}$. Ewes were used as recipients during the second cycle after sponge withdrawal.

Embryo transfer. Embryos were recovered and transferred after mid-ventral laparotomy performed while the ewes were under general anaesthesia which was induced and maintained by mixtures of oxygen, nitrous oxide and halothane (Fluothane: ICI Ltd, Macclesfield, Cheshire). On Day 3, embryos were recovered from the oviduct by inserting a fine nylon catheter into the fimbriated end of the oviduct and flushing fluid from the uterus through the utero-tubal junction and oviduct and into a collecting dish (Hunter, Adams \& Rowson, 1955). When the ewes had reached Days 6, 9 or 12, embryos were recovered from the uterus by inserting a Foley catheter (10 FG, $3 \mathrm{ml}$ balloon; Willy Rusch Ltd, Stuttgart, W. Germany) into the uterine lumen at the base of the horn, and introducing fluid at the top of the horn through a blunted 18-gauge needle. All manipulations of the embryos were carried out in phosphate-buffered saline, $\mathrm{pH} \mathrm{7.2,}$ enriched with protein and energy sources (Whittingham, 1971). Embryos were transferred into the uterine lumen of the recipient with a Pasteur pipette whose tip had been rounded in a flame (Hunter et al., 1955).

Experiment 1. Two embryos, one synchronous and one markedly asynchronous, were transferred into each of 15 ewes. The aim was to transfer a perfectly synchronous embryo and an embryo from a donor 3 days out of phase with the recipient. However, 2 ewes received 'synchronous' embryos from donors that were $12 \mathrm{~h}$ and 1 day out of phase respectively and 'asynchronous' embryos from donors 4 days out of phase.

The recipients were all Blackface ewes, the donors were Blackface, Wensleydale, Cheviot or Finn-Dorset. The two embryos transferred to a recipient were from breeds whose lambs could readily be distinguished. Recipients were observed for a possible return to oestrus and those that conceived were allowed to lamb. Details are shown in Table 1.

Table 1. Number of lambs born after transfer of a 'synchronous' and asynchronous embryo to a 'single' recipient

\begin{tabular}{|c|c|c|c|c|}
\hline \multirow{2}{*}{$\begin{array}{l}\text { Day of } \\
\text { cycle of } \\
\text { donors }\end{array}$} & \multicolumn{2}{|c|}{ Recipients } & \multicolumn{2}{|c|}{ No. of lambs from: } \\
\hline & $\begin{array}{l}\text { No. of } \\
\text { ewes }\end{array}$ & $\begin{array}{l}\text { Day of } \\
\text { cycle }\end{array}$ & $\begin{array}{c}\text { Synchronous } \\
\text { egg }\end{array}$ & $\begin{array}{c}\text { Asynchronous } \\
\text { egg }\end{array}$ \\
\hline $\begin{array}{l}7 \\
4\end{array}$ & 6 & 7 or 8 & 4 & 0 \\
\hline $\begin{array}{l}6 \\
9\end{array}$ & 9 & 6 & 6 & 0 \\
\hline
\end{tabular}

Experiment 2. Blackface ewes were used to study the effect on Day-3 embryos and Day-6 embryos of 3 days exposure to the uterine environment of a recipient which had been in oestrus 3 days before the donor. The stage of development of the embryos and their ability to implant when transferred to a second recipient synchronous with the original donors were compared with those of embryos subjected to two synchronous transfers. Details of the experimental design are shown in Table 2. Transfer to a recipient in oestrus 3 days before the donor with no second transfer (Groups 1a and 2a) was intended to show the inability of such a transferred embryo to establish pregnancy in the conditions of our experiments.

The recipients in Groups $1 \mathrm{a}$ and $2 \mathrm{a}$, and the second recipients in the other groups all received 1 or 2 embryos. The first recipient in Groups $1 b, 1 c, 2 b$ and $2 c$ received various numbers of embryos, mostly 3 or 4 , but up to 9 . There is no evidence of competition at these stages in sheep which have been induced to superovulate (Robinson, 1951). When possible, the embryos from one donor were used in more than one treatment. At the time of the second transfer the stage of 
development of the embryos was recorded and they were photographed under bright-field and phase-contrast microscopy.

The second recipients were observed for a return to oestrus and slaughtered 32-41 (Group 1) or 51-58 (Group 2) days after oestrus. Embryos were recovered from the uterus, the crown-rump length was measured and the normality of development was assessed.

Table 2. Design of Exp. 2 to investigate the effects on a 3-or 6-day embryo of exposure for 3 days in the uterus of a 6- or 9-day recipient

\begin{tabular}{|c|c|c|c|c|}
\hline \multirow[b]{2}{*}{ Group } & \multirow[b]{2}{*}{ Donor } & \multicolumn{2}{|c|}{ Stage of cycle (days) } & \multirow{2}{*}{$\begin{array}{c}\text { Age of embryo at } \\
\text { second transfer } \\
\text { (days) }\end{array}$} \\
\hline & & Ist recipient & 2 nd recipient & \\
\hline la & 3 & 6 & - & \\
\hline $1 b$ & 3 & 3 & 6 & 6 \\
\hline $1 \mathrm{c}$ & 3 & 6 & 6 & 6 \\
\hline $2 a$ & 6 & 9 & - & - \\
\hline $2 b$ & 6 & 6 & 9 & 9 \\
\hline $2 c$ & 6 & 9 & 9 & 9 \\
\hline
\end{tabular}

\section{Results}

\section{Experiment 1}

Of the 15 recipients, 11 lambed and each produced 1 lamb (Table 1). All the lambs had developed from the embryo recovered from a 'synchronous' donor.

\section{Experiment 2}

The proportion of embryos transferred into 1 st recipients and recovered as apparently viable embryos was $36,59,48$ and $50 \%$ for Groups $1 \mathrm{~b}, 1 \mathrm{c}, 2 \mathrm{~b}$ and $2 \mathrm{c}$ respectively. In Groups $2 \mathrm{~b}$ and $2 \mathrm{c}$ a further 7 and $27 \%$ of the embryos were recovered as degenerating embryos. No. degenerating embryos were recovered from Groups $1 \mathrm{~b}$ and $1 \mathrm{c}$ apart from those which were believed to be the unfertilized eggs of the recipient. The results presented below are of developmental stage and implantation rate of embryos which were considered to be viable and were transferred into 2 nd recipients. This form of presentation underestimates the effects of asynchrony if the incidence of degeneration observed in Groups $2 b$ and $2 c$ accurately reflects the pattern of degeneration after asynchronous transfer.

Effects on stage of development. Of the 74 embryos recovered from donors on Day 6, 58 (78\%) were morulae and $16(22 \%)$ were early blastocysts. In Group 1b there were $8(80 \%)$ morulae and 2 early blastocysts, but in Group $1 \mathrm{c}$ there were only $7(47 \%)$ morulae and 8 early blastocysts. These frequencies differ significantly $(P<0.05$, Fisher Exact test). There was a more striking difference between Groups $2 \mathrm{~b}$ and $2 \mathrm{c}$ in which there were respectively $3(20 \%)$ and 0 embryos in an expanded zona, $9(60 \%)$ and $3(19 \%)$ small hatched blastocysts and $3(20 \%)$ and $13(81 \%)$ large hatched blastocysts $(P<0.005$, Fisher Exact test). The large hatched blastocysts in Group $2 \mathrm{c}$ were unexpectedly large and dark, suggesting the presence of more cells than usual. In one embryo the germinal disc clearly protruded through the trophoblast, as described for a normal Day-10 embryo (Fléchon, 1978).

Effects on implantation rate and embryo size. There were no implantations from the 15 embryos transferred into and left in an asynchronous recipient (Groups 1a and 2a). In the other groups, conception rate and implantation rate were similar except after exposure of Day- 6 morulae to a Day- 9 ewe for 3 days (Group 2c) when overall survival was $14 \%$ compared to 70 , 62 and $50 \%$ in Groups $1 \mathrm{~b}, 1 \mathrm{c}$ and $2 \mathrm{~b}$ respectively. 
The implantation data summarized in Table 3 were analysed by fitting a linear-model using a logistic link function (GLIM computer program; Royal Statistical Society). This showed that there was significant variation between recipients in the success of a transfer, and that Group $2 \mathrm{c}$ was less successful than Groups $1 \mathrm{~b}, 1 \mathrm{c}$ and $2 \mathrm{~b}(P<0.05)$.

Table 3. Survival of embryos in Exp. 2

\begin{tabular}{ccccc}
\hline Group & $\begin{array}{c}\text { No. of } \\
\text { ewes }\end{array}$ & $\begin{array}{c}\text { No. of } \\
\text { embryos }\end{array}$ & $\begin{array}{c}\text { No. } \\
\text { pregnant }\end{array}$ & $\begin{array}{c}\text { No. of } \\
\text { fetuses }\end{array}$ \\
\hline la & 4 & 5 & 0 & 0 \\
1b & 6 & 10 & 4 & 7 \\
1c & 9 & 16 & 7 & 10 \\
2a & 5 & 10 & 0 & 0 \\
2b & 8 & 14 & 5 & 7 \\
2c & 10 & 14 & 2 & 2 \\
\hline
\end{tabular}

The effect of treatment on embryo crown-rump length was also examined. After adjusting for differences in slaughter date, the estimated mean lengths at Day 37 were 20.7 and $29.0 \mathrm{~mm}$ for Groups $1 \mathrm{~b}$ and $1 \mathrm{c}$ respectively. The daily rate of increase in length is about $12 \%$ at this stage, which gives an estimated difference between the groups of 2.9 days with a standard error of 1.3 days.

\section{Discussion}

These experiments provide new understanding of the cause of embryonic death after asynchronous transfer and of the critical time when the environment first modifies the embryo. It is clear that sheep embryos that are transferred into an advanced asynchronous recipient fail to implant because their development is fatally modified. As they fail to inhibit luteolysis, such embryos are ultimately expelled from the uterus during pro-oestrus of the following cycle (R. A. S. Lawson \& L. Cahill, personal communication) but lose the potential for normal development during the 2 nd week after mating.

These results confirm and extend the observations (unpublished) of R. A. S. Lawson \& L. Cahill who transferred an asynchronous and a synchronous embryo into 9 ewes: 6 ewes received advanced embryos and 3 ewes received retarded embryos; 8 ewes conceived, but all the fetuses were from the synchronous transfer. Taken in conjunction with the observations in Exp. 1, these results provide convincing evidence that a synchronous embryo which prevents luteolysis and establishes pregnancy is unable to protect an asynchronous embryo and allow it to develop to term. As reported by others, embryos transferred into recipients which were oestrus 3 days before the donors were unable to implant (see Rowson \& Moor, 1966).

The apparently advanced state of development of embryos recovered after 3 days in a recipient which had been in oestrus 3 days earlier than the donor extends observations by Lawson (1977). However, these present observations also established that the effects of the environment vary with the stage of development and that exposure for only 3 days may fatally modify development. Further studies are being carried out to determine whether the difference between stages reflects changes in the sensitivity of the embryo, or changes in the uterine environment or both. It may be that Day-3 to Day-6 embryos are insensitive to the factors which modified Day-6 to Day-9 embryos, or that the uterine factors concerned are present on Days $9-12$ but not on Days 6-9.

The inability to implant in a second recipient could reflect an abnormal development or the apparently advanced stage of development. At this time the embryos were equivalent in age to Day- 9 embryos, but had the appearance of Day-10 or -11 embryos. Although transfer of 
Day-11 embryos into Day-9 recipients has not been carried out, it would be expected to yield conception rates around 50\% (Rowson \& Moor, 1966) compared with 2 of 10 recipients conceiving in Group 2c ( 2 of 14 embryos survived). This difference suggests that, although the embryos were larger than embryos transferred synchronously and apparently normal, the development should be considered to be abnormal rather than accelerated along the normal path.

The effect in sheep is apparently different from that observed in rabbits (Adams, 1971) or rat (Dickmann \& Noyes, 1960) in that embryos of these species were degenerate after only a few hours in the unusual environment. By contrast, the embryos in Group $2 c$ of Exp. 2 were larger and not evidently moribund.

Unlike asynchronously transferred morulae, the earlier stage embryos (Group 1c) were not fatally affected by the asynchronous environment. Indeed, conception rate after second transfer was high and fetuses were larger than after double synchronous transfer, although these effects must be confirmed in future experiments. A similar effect has been observed after a single transfer in rats (Noyes, Doyle, Gates \& Bentley, 1961) and mice (Aitken, Bowman \& Gould, 1977) when transfer of embryos from a donor which was in oestrus before the recipient was followed by attainment of a greater fetal weight. The effect in mice and rats was attributed to the longer period available for growth of the embryo and trophoblast before implantation (Aitken $e t$ al., 1977).

These results may also have implications for the normal development of the uterus and the embryo. The way in which progesterone concentration increases apparently plays a major role in determining the stage of development of the uterus. Day-10 sheep embryos implanted normally after transfer to recipients on Day 6 after oestrus if the recipients had been given daily injections of progesterone from the day of oestrus (R. A. S. Lawson \& L. Cahill, personal communication). Furthermore, in ovariectomized ewes receiving injections of progesterone and oestradiol, a difference of only $1 \frac{1}{2}$ days in the time of the increase in progesterone concentration dramatically altered the conception rate after embryo transfer (Miller \& Moore, 1976). In spite of this function, there appear to be considerable variations in progesterone concentrations between ewes (see Thorburn, Bassett \& Smith, 1969), although characteristics such as the timing of increased progesterone concentration and the rate of increase have not been adequately reported for individual ewes. Similarly, it is known that there is great variation in the stage of development of embryos recovered on any particular day after oestrus (see WintenbergerTorres, 1967). On Days 1-5 the variation was equivalent to $0.5-1.8$ cell devisions (Wintenberger-Torres, 1967) and by fitting a linear regression to her estimates of cell number after a $\log$ transformation, it can be estimated that each cleavage requires approximately $22 \cdot 5 \mathrm{~h}$.

It is postulated that luteal function and early embryo development (at least to Day 4) are sufficiently independent to allow a significant spontaneous asynchrony to develop, and that in the 2 nd week after mating this causes abnormal embryo development which leads to embryonic death. As there is variation in the stage of embryo development within a ewe which has several ovulations, such asynchrony need not affect every embryo.

We thank Dr L. Cahill for unpublished information and invaluable advice, Miss M. R. Thomson for the experimental surgery, Mr J. C. Manson for the anaesthesia and $\mathrm{Mr} \mathrm{A}$. Macgregor and his staff for care of the sheep.

\section{References}

Adams, C.E. (1971) The fate of fertilized eggs transferred to the uterus or oviduct during advancing pseudopregnancy in the rabbit. J. Reprod. Fert. 26, 99-111.
Adams, C.E. (1975) Recovery and Transfer of Mammalian Eggs. Bibliography No. 89. Reproduction Research Information Services Ltd, Cambridge. 
Adams, C.E. \& Abbott, M. (1971) Recovery and Transfer of Mammalian Eggs and Ovarian Transplantation. Bibliography No. 45. Reproduction Research Information Services Ltd, Cambridge.

Aitken, R.J., Bowman, P. \& Gould, I. (1977) The effect of synchronous and asynchronous egg transfer on fetal weight in mice selected for large and small body size. J. Embryol. exp. Morph. 37, 59-64.

Chang, M.C. (1950) Development and fate of transferred rabbit ova and blastocysts in relation to the ovulation time of the recipients. J. exp. Zool. 114, 197-225.

Dickmann, Z. \& Noyes, R.W. (1960) The fate of ova transferred into the uterus of the rat. J. Reprod. Fert. 1, 197-212.

Fléchon, J.E. (1978) Morphological aspects of embryonic disc at the time of its appearance in the blastocyst of farm animals. Scanning Electron Microscopy 11, 541-548.

Hunter, G.L., Adams, C.E. \& Rowson, L.E.A. (1955) Inter-breed ovum transfer in sheep. J. agric. Sci., Camb. 46, 143-149.

Lawson, R.A.S. (1977) Research applications of embryo transfer in sheep and goats. In Embryo Transfer in Farm Animals, pp. 72-78. Ed. K. J. Betteridge. Canada Department of Agriculture, Ottawa.

Miller, B.G. \& Moore, N.W. (1976) Effects of progesterone and oestradiol on RNA and protein metabolism in the genital tract and on survival of embryos in the ovariectomized ewe. Aust. J. biol. Sci. 29, 565-573.
Moore, N.W. \& Shelton, J.N. (1964) Egg transfer in sheep. Effect of degree of synchronization between donor and recipient, age of egg, and site of transfer on the survival of transferred eggs. J. Reprod. Fert. 7 , 145-152.

Noyes, R.W., Doyle, A.B., Gates, A.H. \& Bentley, D.L. (1961) Ovular maturation in fetal development. Fert. Steril. 12, 405-410.

Robinson, T.J. (1951) The control of fertility in sheep. II. The augmentation of fertility by gonadotrophin treatment of the ewe in the normal breeding season. J. agric. Sci., Camb. 41, 6-63.

Rowson, L.E.A. \& Moor, R.M. (1966) Embryo transfer in the sheep: the significance of synchronizing oestrus in the donor and recipient animal. J. Reprod. Fert. 11, 207-212.

Thorburn, G.D., Bassett, J.M. \& Smith, I.D. (1969) Progesterone concentration in the peripheral plasma of sheep during the oestrous cycle J. Endocr. 45, 459-469.

Whittingham, D.G. (1971) Survival of mouse embryos after freezing and thawing. Nature, Lond. 233, $125-126$.

Wintenberger-Torres, S. (1967) Action de la progesterone et des steroids ovarians sur la segmentation des oeufs chez la brebis. Annls Biol. anim. Biochim. Biophys. 7, 391-406.

Received 2 May 1980 